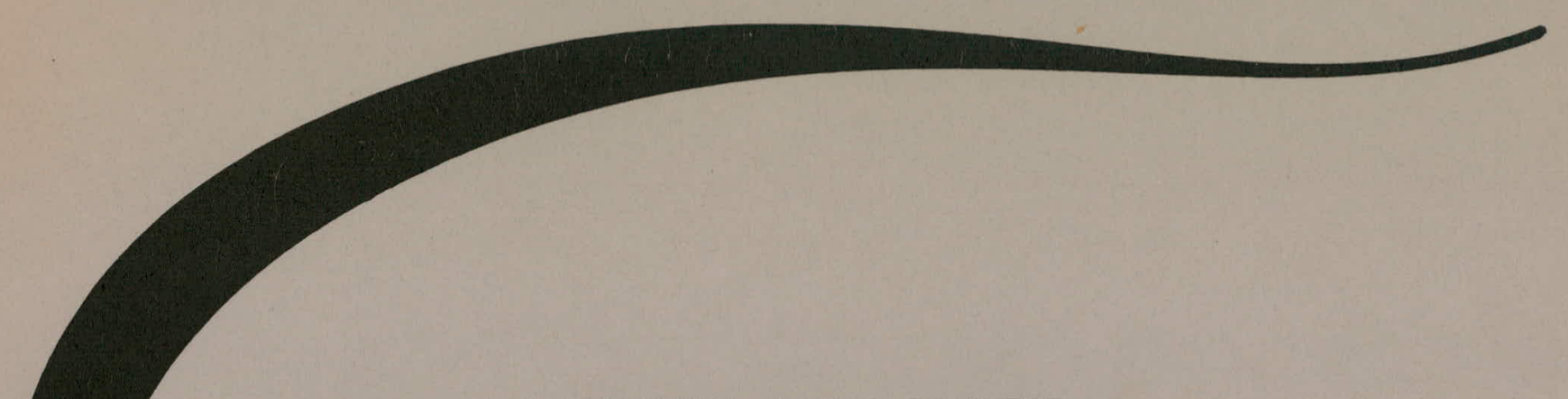

A PERSONAL ALPHA COUNTER

WITH AURAL READOUT

William H. Tyree

Thomas H. Bell

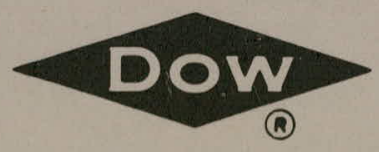

DOW CHEMICAL U.S.A.

ROCKY FLATS DIVISION

P. O. BOX 888

GOLDEN, COLORADO 80401

U.S. ATOMIC ENERGY COMMISSION

CONTRACT AT(29-1)-1106 


\section{DISCLAIMER}

This report was prepared as an account of work sponsored by an agency of the United States Government. Neither the United States Government nor any agency Thereof, nor any of their employees, makes any warranty, express or implied, or assumes any legal liability or responsibility for the accuracy, completeness, or usefulness of any information, apparatus, product, or process disclosed, or represents that its use would not infringe privately owned rights. Reference herein to any specific commercial product, process, or service by trade name, trademark, manufacturer, or otherwise does not necessarily constitute or imply its endorsement, recommendation, or favoring by the United States Government or any agency thereof. The views and opinions of authors expressed herein do not necessarily state or reflect those of the United States Government or any agency thereof. 


\section{DISCLAIMER}

Portions of this document may be illegible in electronic image products. Images are produced from the best available original document. 


\section{LEGAL NOTICE}

This report was prepared as an account of work sponsored by the United States Government. Neither the United States nor the United States Atomic Energy Commission, nor any of their employces, nor any of their contractors, subcontracturs, ui thcir cmployees, makes any warranty, expressed or implied, or assumes any legal liability or responsibility for the accuracy, completeness or usefulness of any information, apparatus, product or process disclosed, or represents that its use would not infringe privately owned rights.

Printed in the United States of America

Available from the

National Technical Information Service

U. S. Department of Commerce

Springfield, Virginia 22151

Price: Printed Copy $\$ 4.00$ Microfiche $\$ 0.95$ 
Printed

November 1, 1973
RFP-2098

UC-37 INSTRUMENTS

TID-4500-R60

\title{
A PERSONAL ALPHA COUNTER WITH AURAL READOUT
}

\author{
William H. Tyree
}

Thomas H. Bell

Research and Ecology HEALTH PHYSICS RESEARCH GROUP

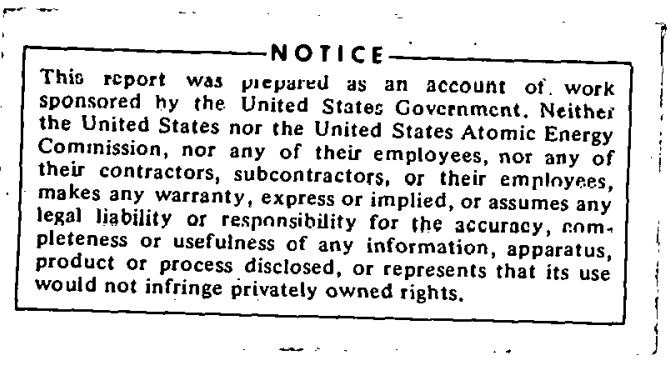

\footnotetext{
DOW CHEMICAL U.S.A. ROCKY FLATS DIVISION

P. O. BOX 888

GOLDEN, COLORADO 80401

Prepared under Contract AT(29-1)-1106

for the

Albuquerque Operations Office

U. S. Atomic Energy Commission
}

\section{SUBJECT DESCRIPTORS}

Alpha Particle Detection

Instrumentation and Controls 
RFP-2098 


\section{CONTENTS}

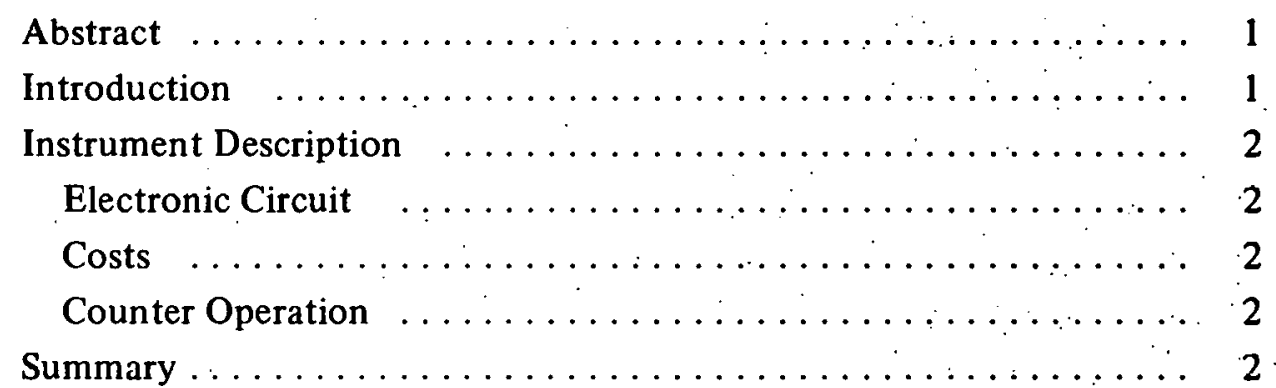


RFP-2098 


\title{
A PERSONAL ALPHA COUNTER WITH AURAL READOUT
}

\author{
William H. Tyree and Thomas H. Bell
}

\begin{abstract}
An Alpha Counter has been developed for use by production operations personnel working in nuclear facilities where contamination control of radioactivity must be carefully exercised. The Counter, worn or carried, provides monitoring capability whenever an operator requires its use. The system for the counter uses a standard Rocky Flats air-proportional detector, a charged energystorage capacitor, and a low power electronic circuit to operate an aural indicator. The alphaparticle counting capability in the system has been achieved at minimum costs.
\end{abstract}

\section{INTRODUCTION}

The primary function of a contamination control operation relates to the containment of radioactive material within environmentally controlled areas. The instrumentation at Rocky Flats has historically used monitoring instruments carried only by Health Physics Operations personnel. The gradual change at Rocky Flats to another system required that both monitors and workers be responsible for their own monitoring. This led to a procedure in which the same operators have their own instruments (counters) available for use after each entrance and exit from glove ports. The instruments in use provide only GO-NO-GO indications of the contamination level on their clothes and hands. The operator has the additional responsibility to aurally determine the approximate level of contamination by listening to the rate at which the output signal device of the counter is producing an audible tone.

The development of this approach to alpha-particle detection instrumentation began in 1960 with tests on various types of polystyrene capacitors. These tests led to the development of the first glove-box alpha-particle counter. ${ }^{3}$

\footnotetext{
${ }^{1}$ W. H. Tyree and V. P. Johnson. An Alphe Counter for Glovebox Operations. RFP-348. Rocky Flats Division, The Dow Chemical Company, Golden, Colorado. August 15, 1963.
}

As the use of these instruments became more widespread, the reliability of the system became an important factor in providing continuous coverage of the various production areas during all shift operations. The charged capacitor system required continuous surveillance, especially during the summer months when high humidity conditions are experienced. The charged capacitor approach was changed to a transistorized single-range alpha counter with a blocking oscillator supply for the detector. ${ }^{2}$ This system provided for continuous operation from rechargeable nickel-cadmium batteries.

The blocking oscillator approach provided for the development of the basic self-monitoring program now in operation at Rocky Flats. The instrument cost varied from $\$ 45$ to $\$ 75$ depending upon quantity of instruments built. Minimum cost permitted use of large quantities of instruments throughout the various production areas for contamination control during three shift operations.

Although each counter is tested for normal operation each day, the counters provide about two weeks of operation before maintenance is required. Usually only the nickel-cadmium battery pack or the detector needs to be changed.

Now that the self-monitoring program is an integral part of the operation of the production areas, a new counter design has been introduced. ${ }^{3}$

The counter utilizes a high voltage battery similar in design to the W-5 battery built by Union Carbide Corporation of New York. The battery provides continuous battery operation of the air-proportional detector even under extremely humid conditions.

\footnotetext{
${ }^{2}$ W. H. Tyree, A Compact Low Cost Alpha Counter. RFP-777. Rocky Flats Division, The Dow Chemical Company, Golden, Colorado. August 17, 1966.

${ }^{3}$ William H. Tyree and Thomas H. Bell. A Single Range Alpha Counter with Aural Alarm. RFP-1807. Rocky Flats Division, Dow Chemical U.S.A., Golden, Colorado. September 21, 1972.
} 
This system also includes a new printed circuit board providing amplification, pulse normalization, and an aural alarm at low quiescent battery current (150 microamperes total circuit).

The various features of the new counter provide for ultra-conservative instrument operation for the various production areas of the plant requiring the utmost in instrument reliability.

The new capacitor-charged alpha particle counter extends the network of contamination control instruments to the personnel most involved with radioactive materials. This capability improves the probability that contamination present from ruptured gloves will be detected at the earliest point in time. That time is at the point where the process operator has just left the glove port, monitors himself, and may detect any presence of contamination on his hands or arms.

\section{INSTRUMENT DESCRIPTION}

The instrument uses an air-proportional detector mounted to the instrument through a UHF coaxial elbow connector. The counter includes a twostage amplifier, 70 millisecond monostable and aural output through an earphone device. The system operates from 3 volts having an operating life of about two months under intermittent conditions. The unit weighs 251.8 grams without the air-proportional detector. The complete counter weighs 355.7 grams. The complete unit is shown in Figures 1 and 2.

\section{Electronic Circuit:}

The circuit utilizes high beta transistors to provide the required gain at extremely low battery power levels. The circuit is shown in Figure 3.

The charge-storage capacitor provides for normal operation of the detector in dry air of 24 hours. The operator charges the unit at the beginning of the shift and at each break.

The battery voltage required is nominally 3 volts. The quiescent current is 100 microamperes. The power dissipation is 300 microwatts. Figure 4 shows the battery current drain with increasing number of detected events.

The unit, as shown in Figures 5, 6, and 7, contains the charged capacitors, printed circuit board, batteries, and aural output.

\section{Costs:}

The cost of the counter, not including the airproportional detector, amounts to $\$ 20$. This includes the completed counter, chargc-storage capacitor, printed circuit board, batteries, and aural alarm. The cost of the detector is $\$ 10$.

\section{Counter Operation:}

The unit is carried in a metal scabbard as shown in Figure 8 to facilitate use by the individual operator. The counter, when detecting the presence of alphaemitting contamination, produces an audible beep for each detected alpha particle. The rate at which the beep takes place indicates the approximate contamination level.

Figure 9 shows the use of the counter by an. nperator for detection of radioactive contamination on his hands.

Figure 10 shows the use of the counter by an operator for detection of radioactive contamination on his clothing.

\section{SUMMARY}

A personal alpha counter for personnel working in production area operations handling radioactive materials has: been described. The counter produces. an aural output for each detected event. The electronic circuitry operates with a 2-millivolt input sensitivity and consumes 100 microwatts of power. The counter costs $\$ 30$ complete with detector, and provides additional personal-counting capability during normal shift operations. 


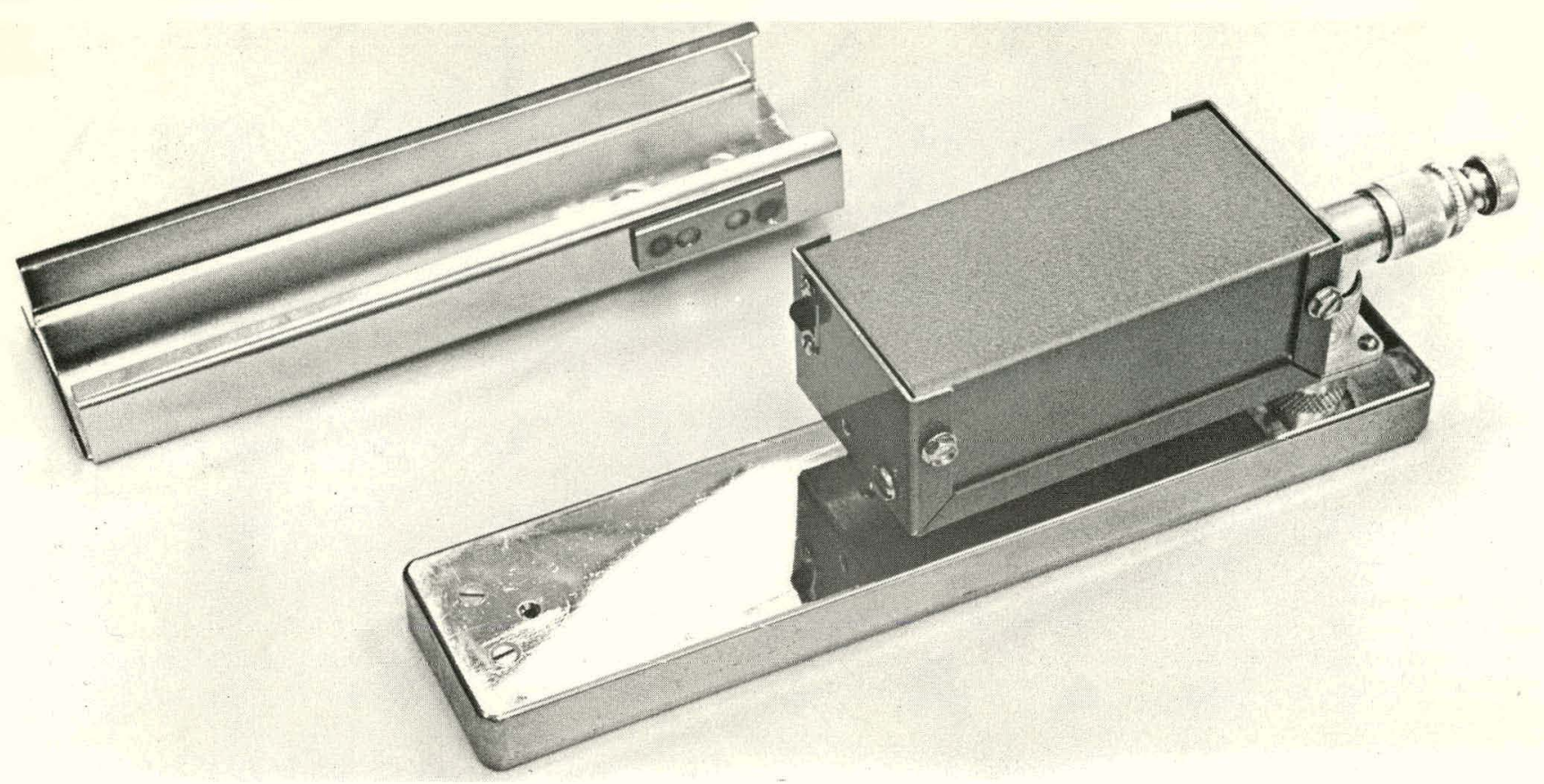

FIGURE 1. Alpha Counter (top view).

16568-2

FIGURE 2. Alpha Counter (front and side view).

16568-1

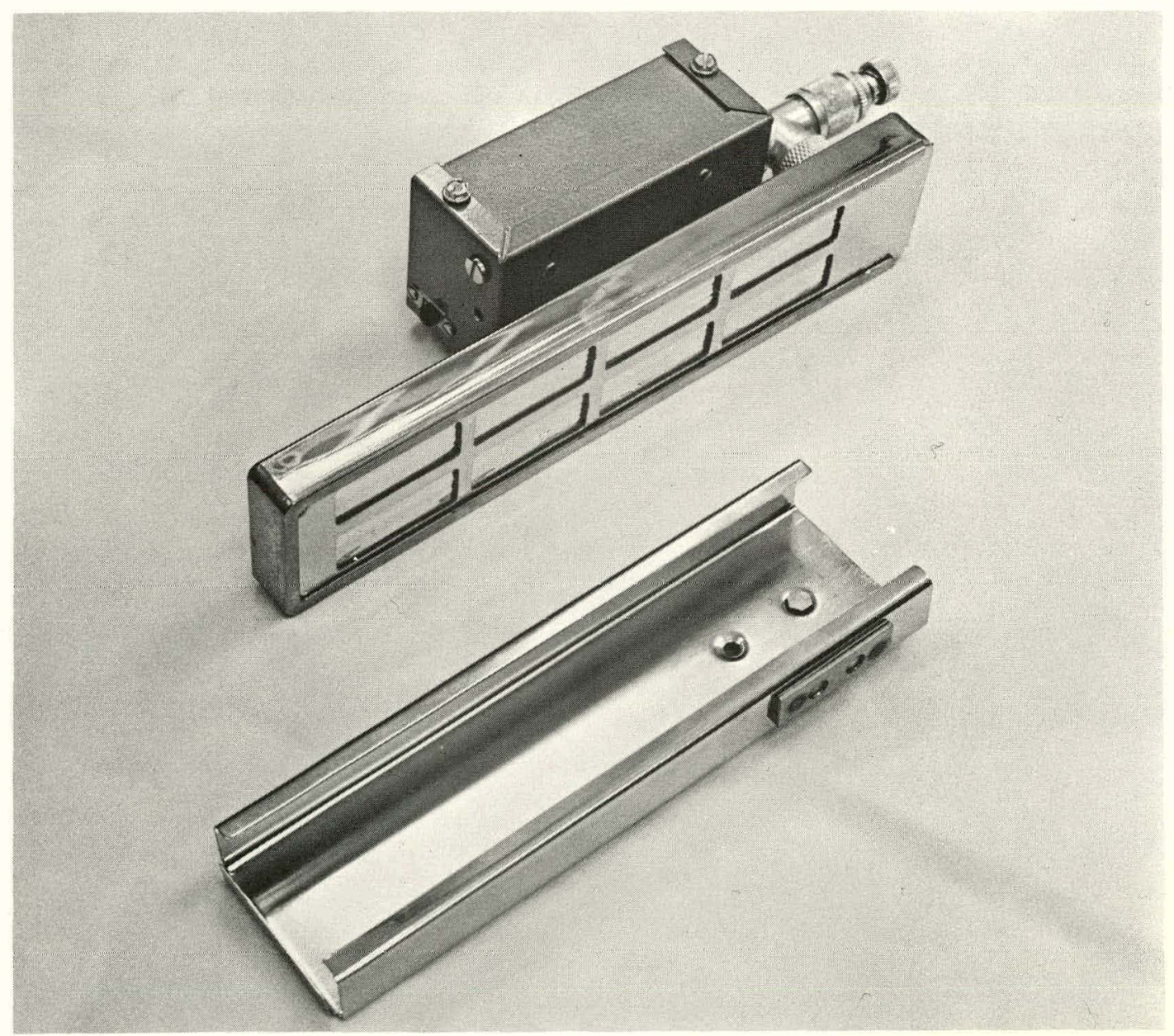




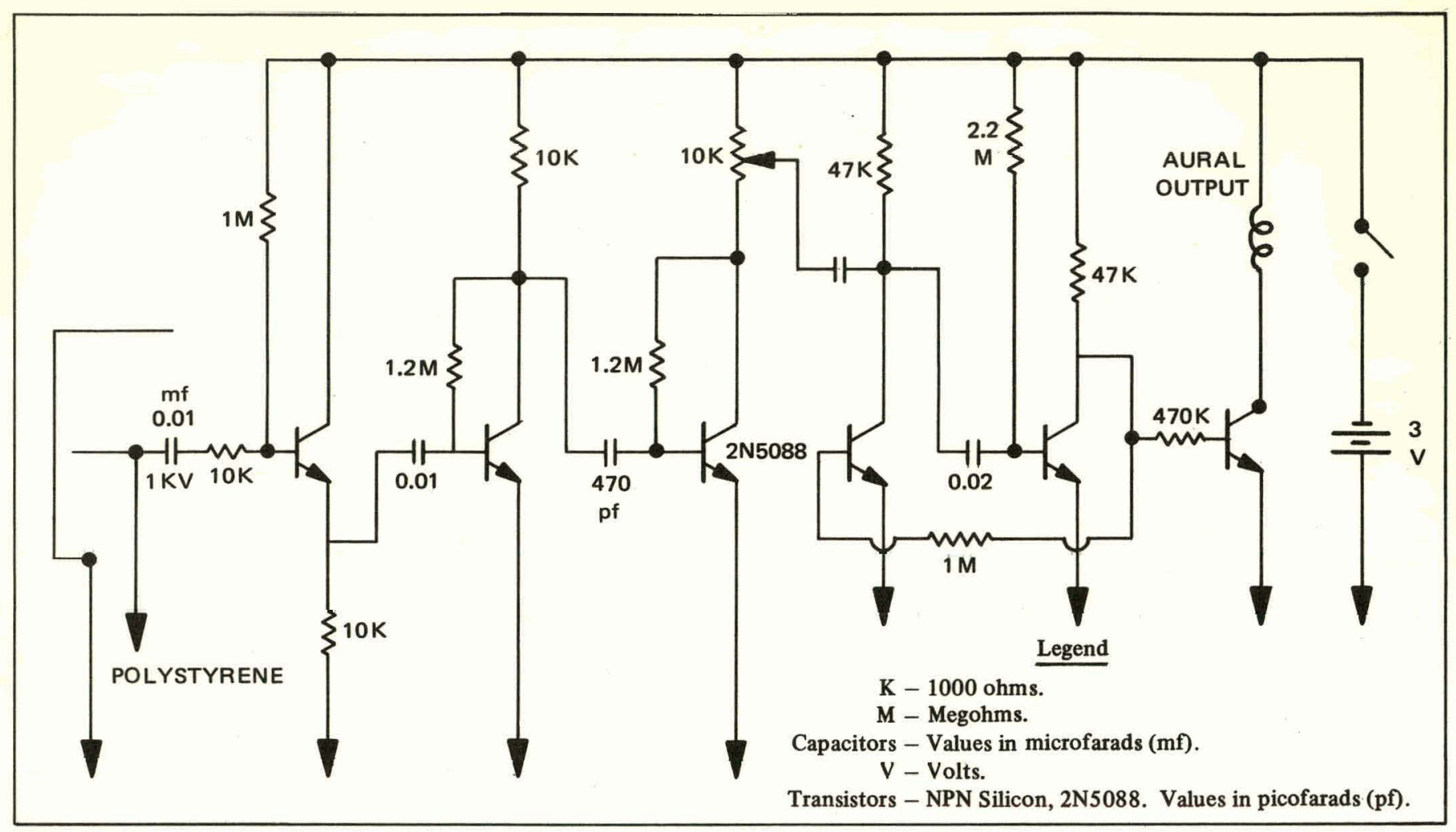

FIGURE 3. Electronic Circuit for Counter.

FIGURE 4. Electronic Circuit Current Drain.

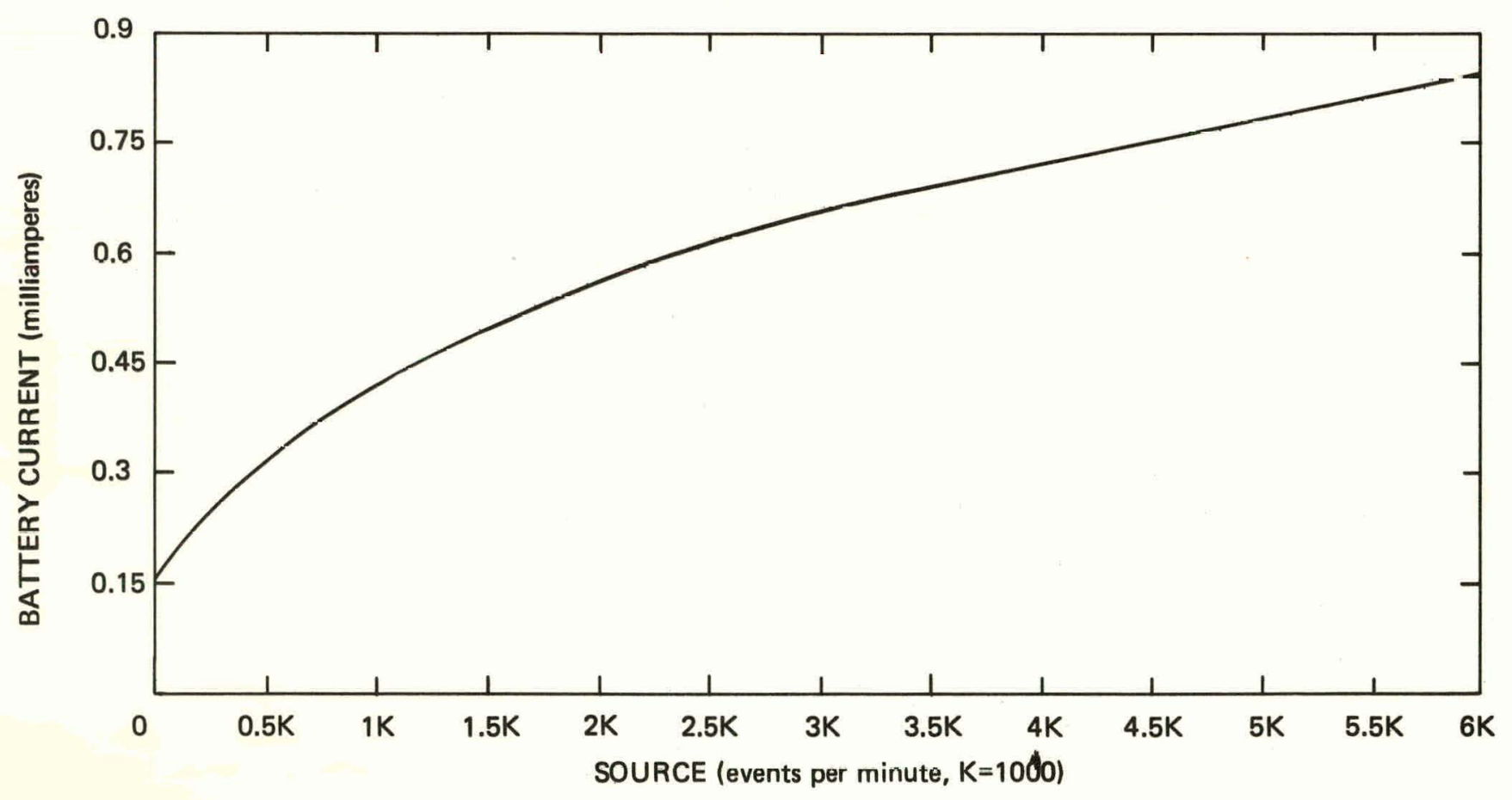


RFP-2098

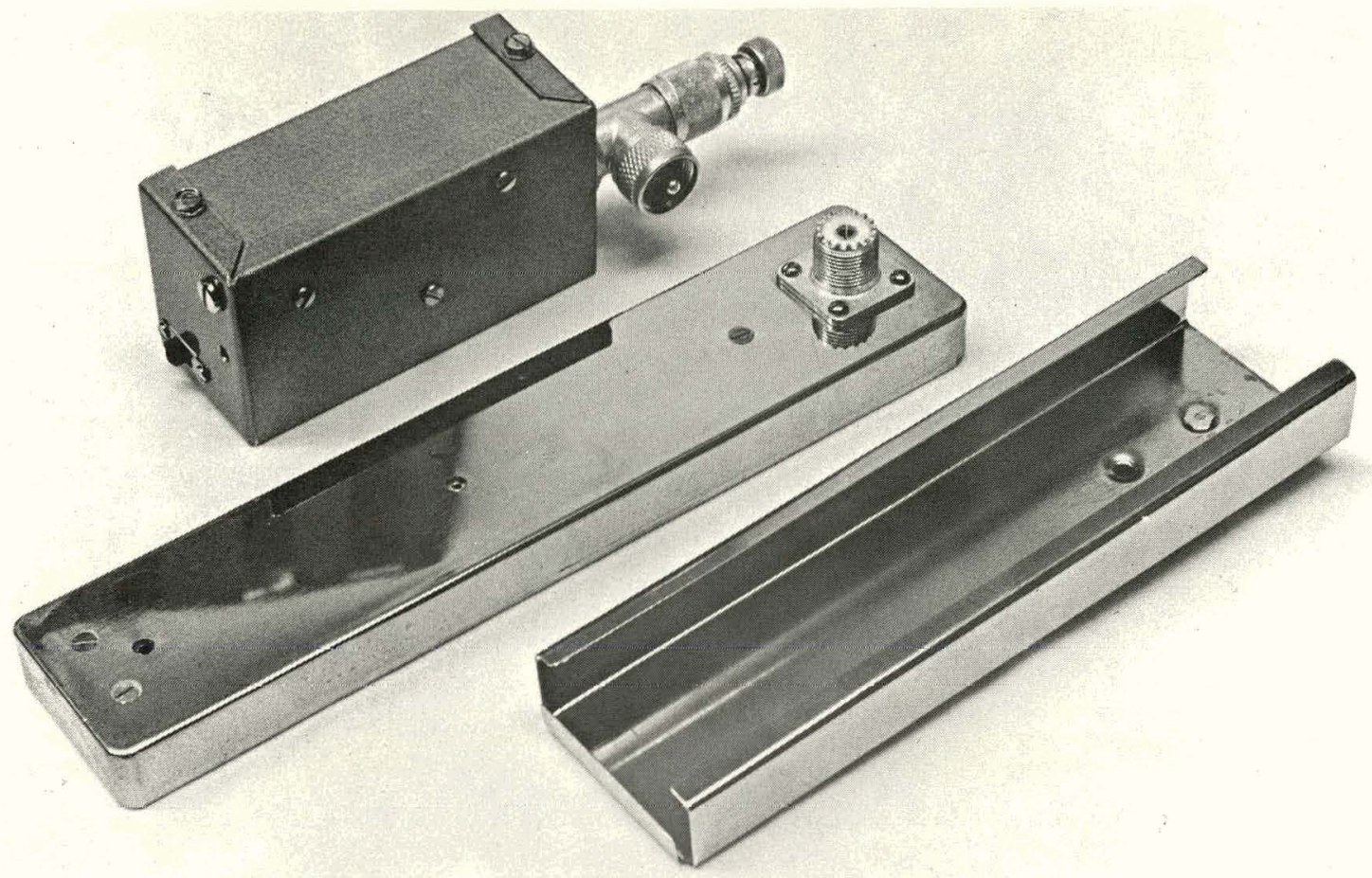

16569-5

FIGURE 5. Counter, Disassembled.

FIGURE 6. Counter-Size Comparison with Respirator.

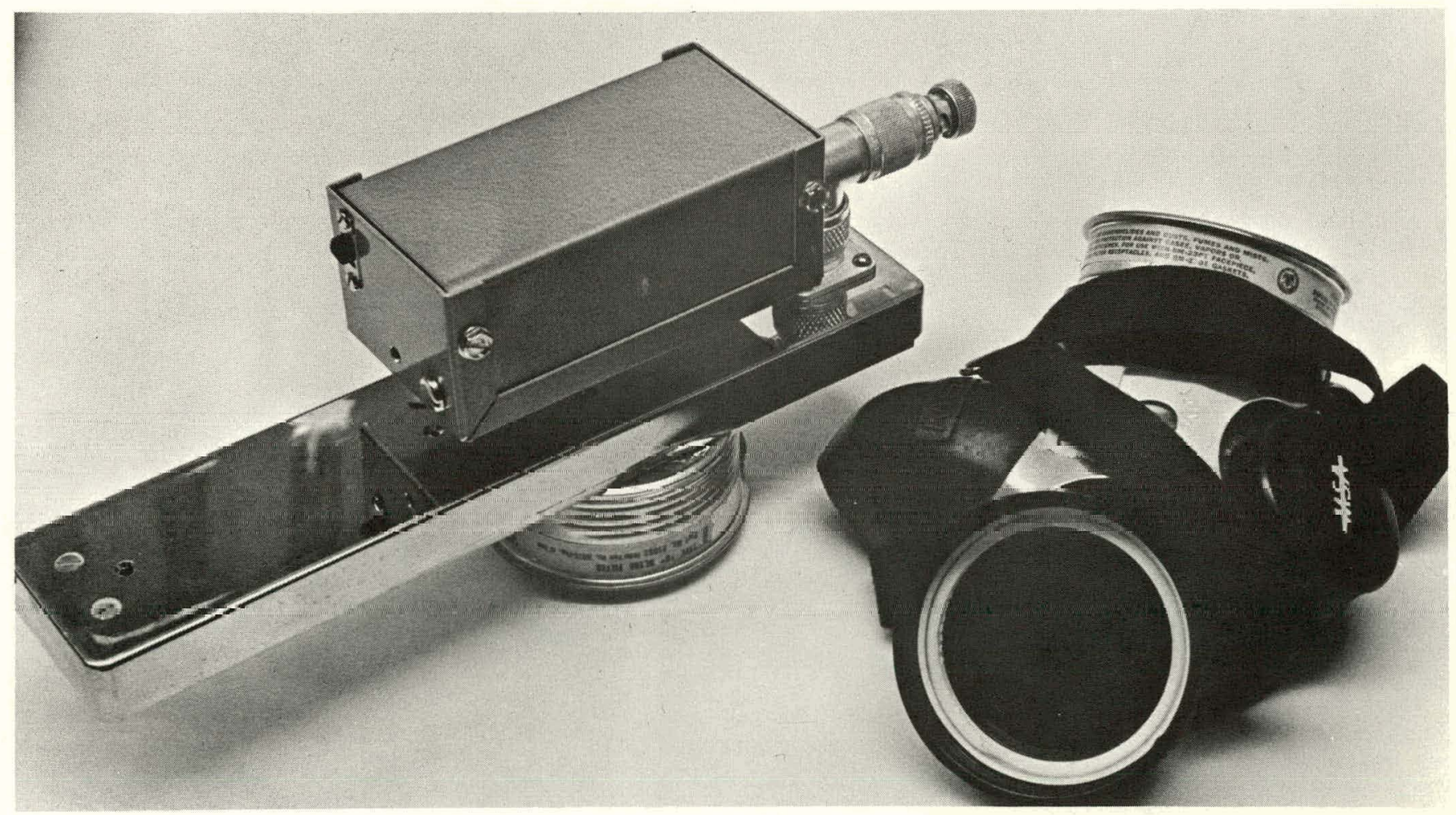


RFP-2098

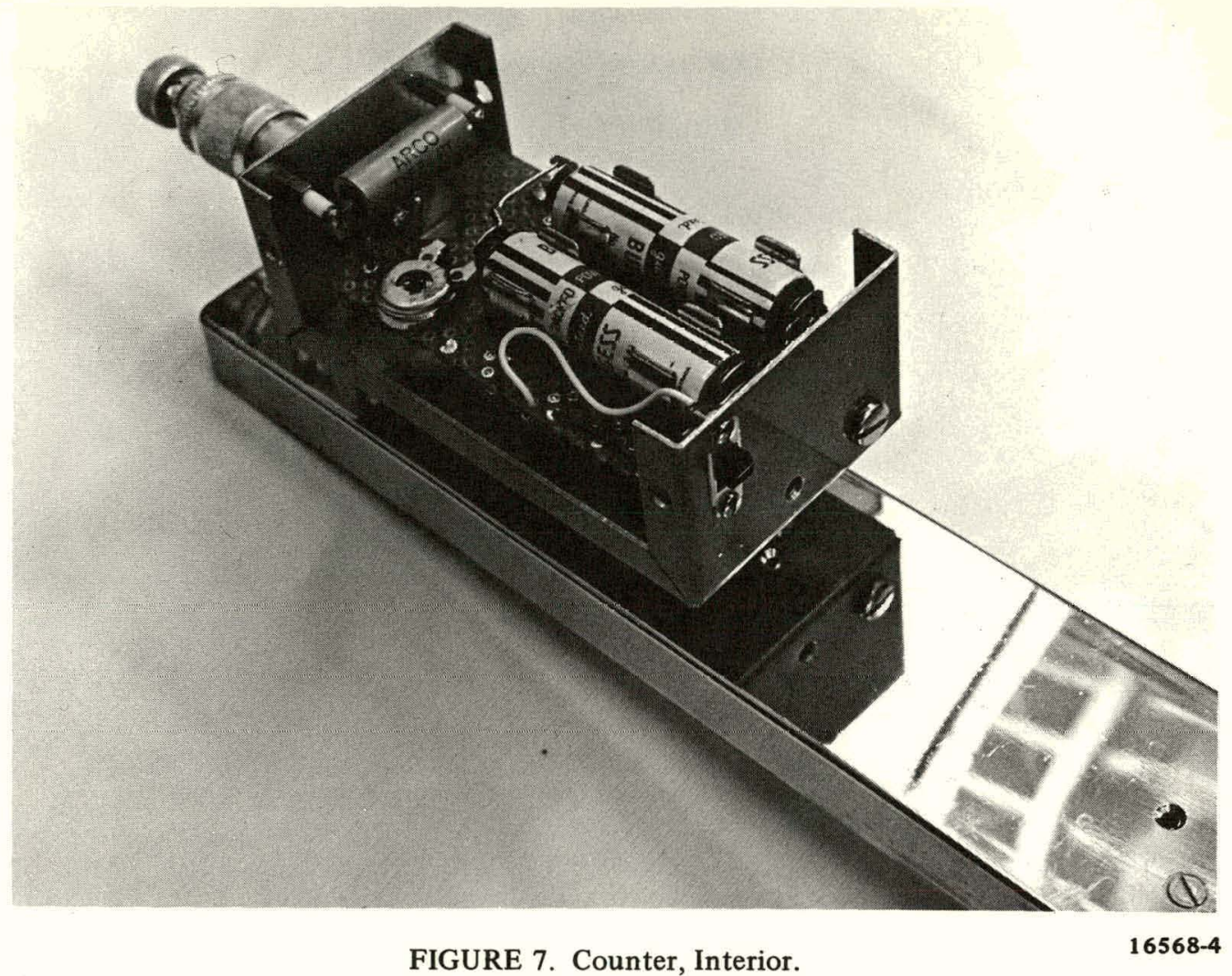

FISIIRF 8 Relt-Mninted Counter

16568-7

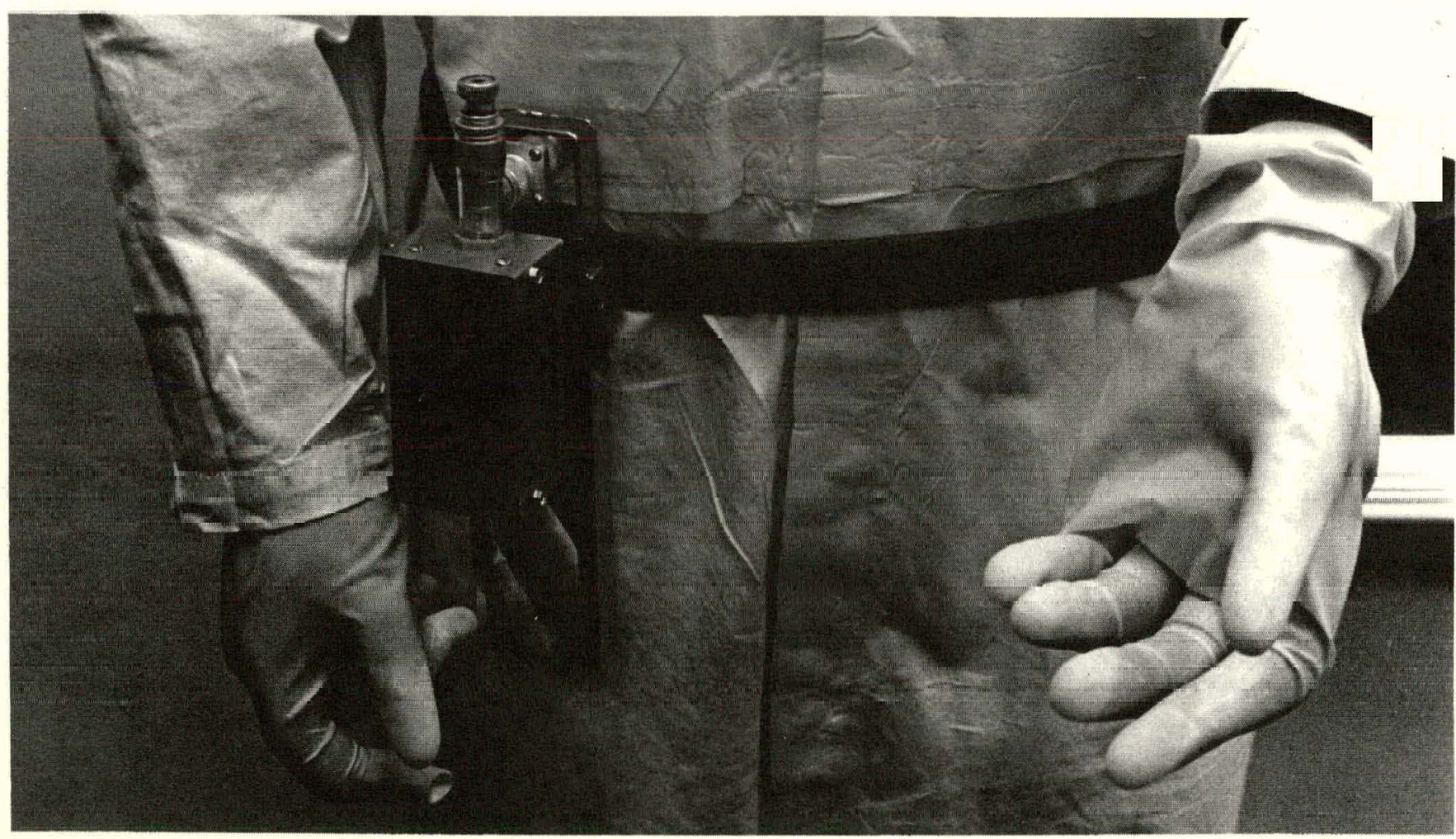


RFP-2098

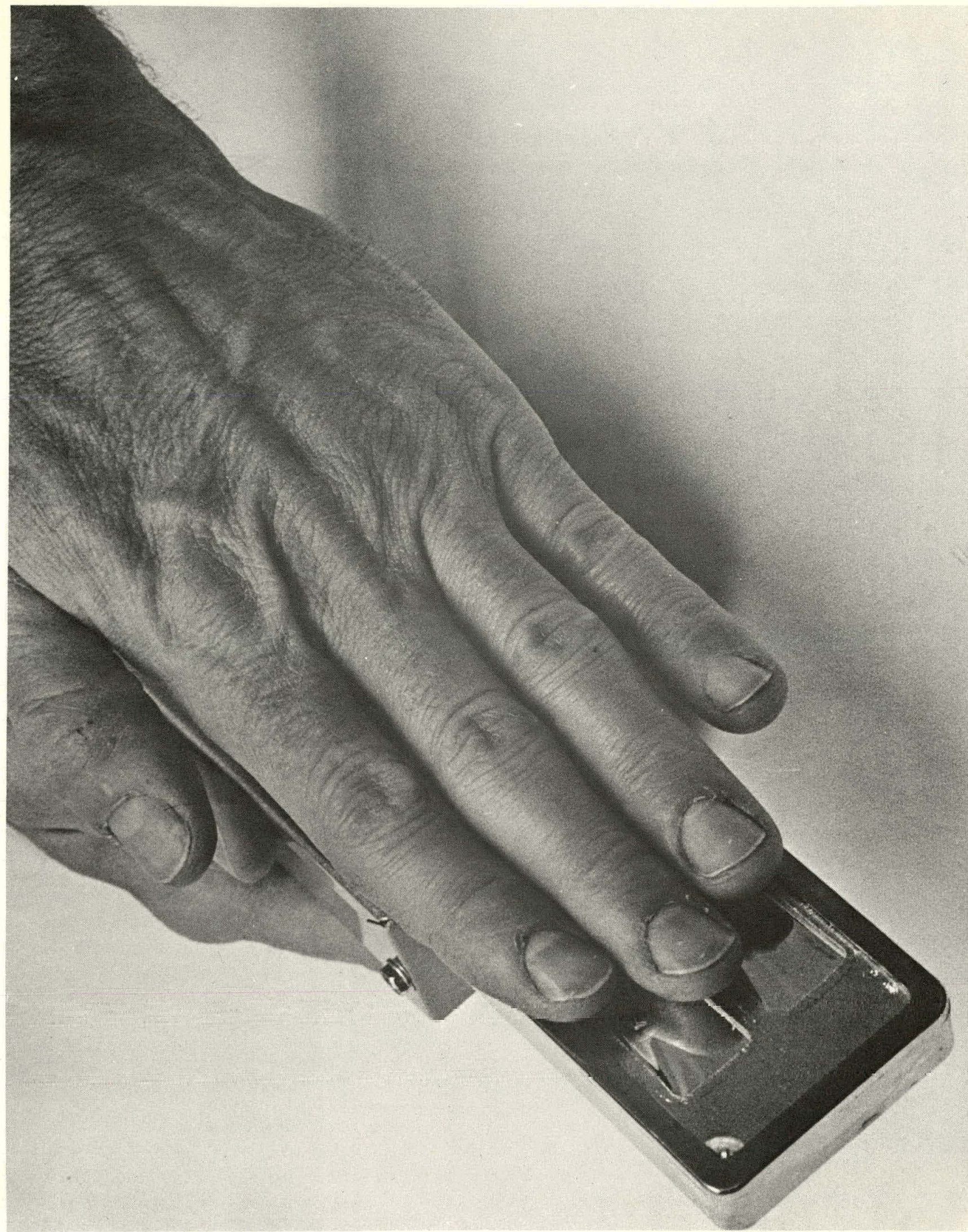

FIGURE 9. Hand Counter. 


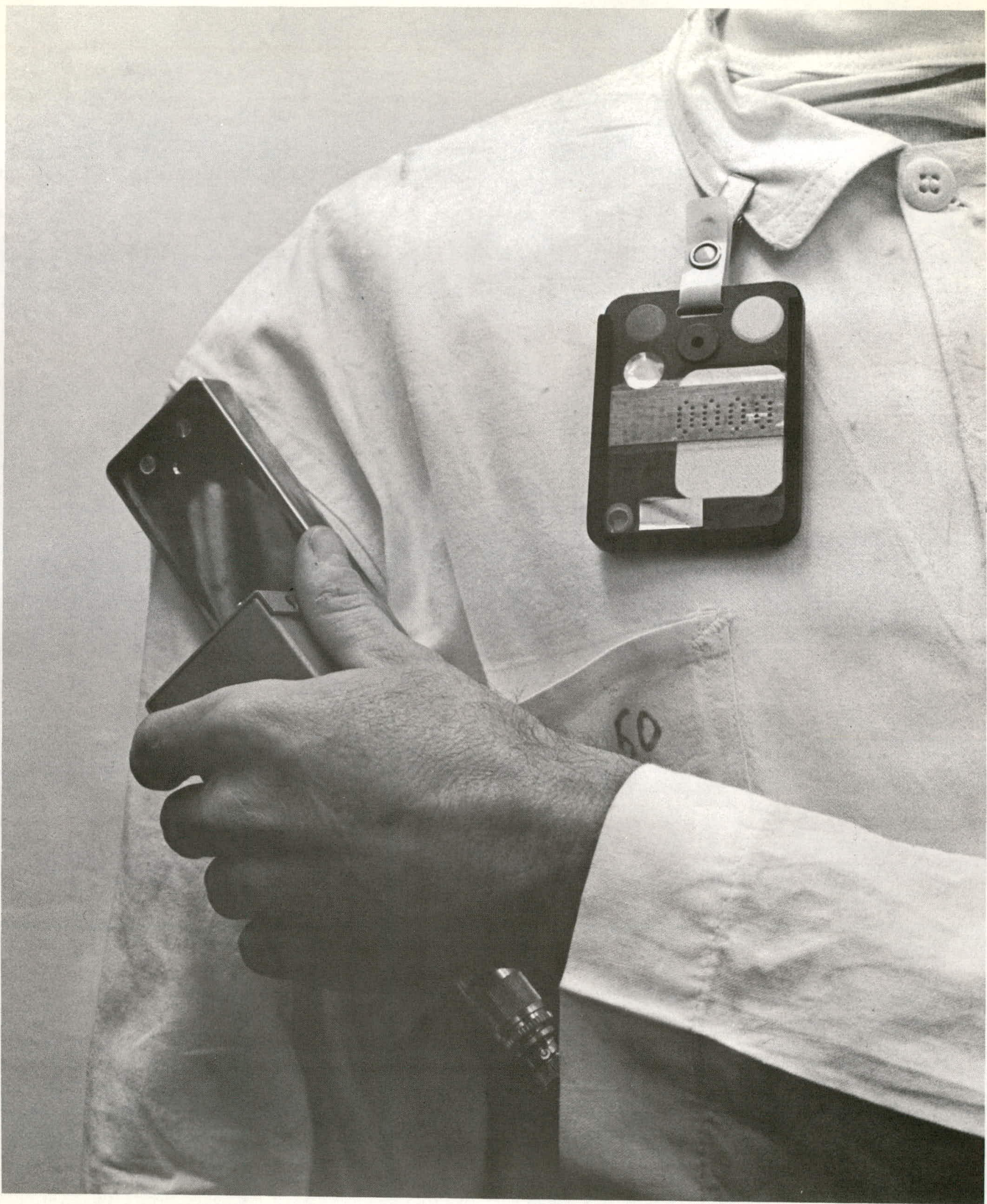

FIGURE 10. Clothing Counter.

16568-8 